\title{
Strategi Pembelajaran Berbasis Masalah Di Taman Kanak-Kanak
}

\section{SITI AISYAH}

Abstrak : Kegiatan pembelajaran mengacu pada kebutuhan dan tingkat perkembangan siswa. Guru sebagai peneglola, memiliki kewajiban untuk memberikan fasilitas terbaik bagi siswa untuk mengembangkan kemampuannya secara optimal. Sebagai subyek pembelajaran, siswa tidak hanya diam dan mendengarkan ceramah dari guru dan mengerjakan seluruh tugas yang diberikan guru, siswa memiliki kesempatan terlibat aktif secara fisik dan mental dalam proses pembelajaran dalam rangka membangun pengetahuannya. pemilihan strategi pembelajaran yang tepat memberikan pengaruh yang signifikan terhadap pencapai tujuan pembelajaran yang telah ditetapkan. Pembelajaran berbasi masalah menjadi solusi dalam meningkatkan kemampuan siswa untuk memecahkan masalah secara kreatif dan inovatif sehingga memberikan motivasi dalam menyelesaikan masalah tersebut.

\section{PENDAHULUAN}

Kegiatan pembelajaran di sekolah dasar saat ini berorientasi pada kemampuan siswa sebagai subyek pembelajaran. Perkembangan ilmu pengetahuan dan teknologi serta penelitian dalam bidang pendidikan membuat perubahan paradigma pembelajaran dari behavioristik yang menekankan pada pembiasaan menjadi konstruktivis yang menekankan pada pengalaman belajar siswa. guru menjadi ujung tombak pelaksanaan kebijakan pemerintah tentang 
standar pendidikan nasional. Kebijakan standar pendidikan yang dikeluarkan oleh pemerintah tidak diikuti dengan pemenuhi standar sarana dan prasarana serta tenaga pendidikan di masing-masing sekolah sehingga kondisi tersebut mengharuskan sekolah untuk mengangkat guru honor atau sukarelawan untuk memenuhi kebutuhan guru. (Mundiri, 2017)

Perubahan paradigma guru dengan gaya mengajar yang konvensional berbeda dengan paradigma pembelajaran dalam kurikulum 2013. Kegiatan pembelajaran yang menekankan pada hafalan dan ulangan hanya menghasilkan kemampuan atau kompetensi pengetahuan level terendah yaitu ingatan. Standar Kegiatan pembelajaran di kelas yang hanya melatih siswa menghafal atau memecahkan soal tertulis saja, tidak akan bisa mengembangkan kreativitas siswa. Hal itu akan mengakibatkan pendidikan yang baik tidak akan pernah terlaksana (Utomo dkk, 2014:6). Dulu para mahasiswa disibukkan dengan hafalan berbagai teori dan konsep penanganan penyakit, namun ketika menghadapi masalah di dunia nyata, terkadang teori yang sudah dikuasai dengan baik belum tentu mampu diterapkan sepenuhnya atau kadang-kadang cara mengatasinya kurang tepat, karena fakta lapangan yang dihadapi sangat bervariasi (Saleh, 2013:192). Pembelajaran yang menggunakan teknik hafalan tidak hanya terjadi di sekolah melainkan juga di Universitas sehingga kemampuan dan kreativitas siswa tidak berkembang dengan baik karena siswa hanya mengingat apa yang disampaikan guru kepada siswa. metode pembelajaran tersebut dinilai tidak efektif dan tidak relevan pada saat ini.

Setiap siswa memiliki potensi kritis dan kreatif, tetapi masalahnya bagaimana cara mengembangkan potensi tersebut melalui proses pembelajaran di 
kelas (Sunaryo, 2014:42). Kreasi dan inovasi dalam kegiatan pembelajaran perlu dikembangkan oleh guru dalam rangka memenuhi standar kompetensi dalam kurikulu. Pemilihan dan penggunaan metode pembelajaran didasarkan pada kesempatan bagi siswa untuk terlibat secara aktif dalam proses pembelajaran. Siswa mampu mengembangkan kemampuannya secara optimal melalui kegiatan pembelajaran yang dirancang oleh guru. Pembelajaran berpusat pada siswa dan siswa terlibat secara aktif dan berinteraksi di dalam kelas untuk membentuk pengetahuan, keterampilan, dan sikapnya secara mandiri. Melalui hubungan di dalam dan di luar kelas, pendekatan CTL menjadikan pengalaman lebih relevan dan berarti bagi peserta didik dalam membangun pengetahuan yang akan mereka terapkan dalam pembelajaran seumur hidup (Saleh, 2013:194).

\section{KAJIAN TEORI}

\section{Pembelajaran}

Karakteristik dari PBM di antaranya adalah: 1) memposisikan siswa sebagai self-directed problem solver melalui kegiatan kolaboratif, 2) mendorong siswa untuk mampu menemukan masalah dan mengelaborasinya dengan mengajukan dugaan-dugaan dan merencanakan penyelesaian, 3) memfasilitasi siswa untuk mengeksplorasi berbagai alternatif penyelesaian dan implikasinya, serta mengumpulkan dan mendistribusikan informasi, 4) melatih siswa untuk terampil menyajikan temuan, dan 5) membiasakan siswa untuk merefleksi tentang efektivitas cara berpikir mereka dalam menyelesaikan masalah (Herman, 2007:48-49). Setiap siswa memiliki keunikan dan kemampuan yang beraneka ragam. Melalui kolaborasi dan kerjasama yang baik siswa mampu 
melakukan berbagi hal yang tidak diduga oleh guru. Setiap siswa memiliki kesempatan yang sama untuk dapat belajar sesuai dengan motivasi dan kebutuhannya. Pertama guru memberikan kesempatan dan keyakinan kepada siswa untuk dapat menyelesaikan setiap peroalan atau tugas dalam kegiatan pembelajaran. Melalui kemampuan berpikir dan menduga siswa mulai mencari tahu cara untuk memecahkan suatu masalah berdasarkan fakta-fakta yang ditemui selama pembelajaran. Belajar pada esensinya adalah memperoleh pengetahuan melalui pengalaman sehingga memiliki keterampilan dalam mengaplikasikannya dengan sikap yang positif. Setiap aktivitas siswa merupakan pengalaman belajarnya dan guru yang baik akan menjadi fasilitator bagi siswa dalam mengoptimalkan kemampuannya dalam memperoleh pelajaran secara mandiri.

\section{Pembelajaran Berbasis Masalah}

Problem Based Learning (PBL), merupakan salah satu model pembelajaran pembelajaran yang menuntut aktivitas mental siswa untuk memahami suatu konsep pembelajaran melalui situasi dan masalah yang disajikan pada awal pembelajaran dengan tujuan untuk melatih siswa menyelesaikan masalah dengan menggunakan pendekatan pemecahan masalah (Utomo dkk, 2014:6). Model pembelajaran berbasis masalah menuntut siswa aktif dalam proses pembelajaran dan memiliki kesempatan untuk menemukan dan menerapkan ide mereka sendiri dalam memecahkan masalah sehingga menunjang siswa untuk mengembangkan kemampuan berpikir kreatifnya. Sementara untuk menentukan benar tidaknya pengetahuan yang diperoleh atau cara pemecahan masalah yang dilakukan, siswa harus mengceknya kembali 
langkah-perlangkah sehingga kemampuan berpikir kritisnya terlatih (Sunaryo, 2014:42). Pembelajaran yang diawali dengan sebuah soal atau permasalahan mengharuskan siswa mengeluarkan seluruh kemampuan berpikirnya untuk menjawab atau memecahkan permasalahan yang ada. Siswa akan mencoba berbagai alternatif solusi yang dianggap mampu menyelesaikan persoalan tersbut. Secara perlahan tetapi pasti, pintu-pintu jawaban akan mulai terbuka dan menggiring siswa pada jawaban yang sesungguhnya. Siswa akan mencoba membuktikan kebenaran yang diperolehnya melalui pembuktian terbalik.

\section{Tahapan Pembelajaran Berbasis Masalah}

Menurut Suprijono (2010:73) bahwa pembelajaran berbasis masalah terdiri dari lima fase dan perilaku. Fase 1: memberikan orientasi tentang permasalahannya kepada siswa, fase 2: mengorganisasikan siswa untuk meneliti, fase 3: membantu investigasi mandiri dan kelompok, fase 4: mengembangkan dan mempresentasikan artefak dan exhibit dan terakhir fase 5: menganalisis dan mengevaluasi proses mengatasi masalah (Sunaryo, 2014:43). Peran seorang guru dalam pembelajaran berbasis masalah antara lain: (1) Merancang dan menggunakan permasalahan yang ada di dunia nyata, sehingga siswa dapat menguasai hasil belajar; (2) Menjadi pelatih siswa dalam proses pemecahan masalah, pengarahan diri dan pembelajaran teman sebaya; (3) Menfasilitasi proses PBM yaitu mengubah cara berpikir, mengembangkan ketrampilan inquiri dan menggunakan pembelajaran kooperatif; (4) Melatih siswa tentang strategi pemecahan masalah, berpikir kritis dan berpikir sistematis; (5) Menjadi perantara proses penggunaan informasi (Rusman dalam Oktaviarini, 2015:79). 
Pertama, kegiatan pembelajaran dirancang dan menggunakan permasalahan yang ada di dunia nyata, sehingga siswa dapat menguasai hasil belajar. Melalui permasalahan yang kontekstual memberikan kemudahan bagi siswa untuk menalar dan mencari alternatif solusi. Guru mengemukakan sebuah permasalahan untuk dipecahkan oleh siswa. kelas dibagi menjadi beberapa kelompok dengan anggota 4 sampai dengan 5 orang setiap kelompok. Setiap kelompok bekerjasama dan berdiskusi membicarakan tentang cara untuk memecahkan masalah yang dikemukakan oleh guru. Meskipun diskusi siswa di taman kanak-kanak hampir seperti perdebatan kecil anak-anak tapi itu cukup efektif dalam melakukan diskusi. Memahami masalah yang dikemukakan dapat memberikan kemudahan bagi siswa untuk memecahkan permasalahan tersebut.

Kedua, guru memberikan kesempatan seluas-luasnya kepada siswa untuk terlibat aktif dalam kegiatan berkomunikasi dan bekerja satu sama lain sehingga akan terbentuk kinerja tim yang saling melengkapi.(Baharun \& Mundiri, 2011) Siswa taman kanak-kanak lebih suka beraktivitas yang melibatkan fisik dari melihat dan mendengarkan. Guru berperan sebagai fasilitator dan motivator serta menyediakan kelas yang kondusif bagi kegiatan belajar siswa. Guru dapat memberikan intervensi apabila dirasa siswa mulai mengalami kesulitan dalam kelompoknya. Guru dapat mengarahkan siswa ke dalam tahapan yang semestinya dan memberikan saran dan masukan sesuai kebutuhan. Guru memberdayakan kemampuan setiap siswa dalam tim agar dapat saling bekerjasama dengan baik. Pembagian kelompok yang heterogen dan proporsional dapat memberikan dampak yang positif terhadap kerjasama kelompok. 
Ketiga, guru menekankan pada pembelajaran kooperatif siswa. masalah yang dipecahkan perorangan hasilnya akan lebih baik apabila dipecahkan oleh beberapa orang yang saling bekerjasama. Cara berpikir siswa dapat dirubah melalui kegiatan pembelajaran yang dapat memberikan pengalaman langsung bagi siswa. melalui berbagai pengalaman, siswa mulai belajar mematangkan cara berpikirnya agar menjadi lebih baik. Cara berpikir tersebut yang menentukan apakah siswa dalam kelompok saling bekerja sama atau bekerja sendiri-sendiri. Melalui pembelajaran kooperatif dan memaksimalkan kemampuan setiap siswa, setiap kelompok akan memiliki banyak cara untuk mencari solusi terhadap permasalahan pembelajaran. Siswa taman kanak-kanak memiliki kesulitas untuk bekerjasama, akan tetapi apabila salah seorang siswa berhasil melakukan sesuatu maka yang lain akan mengikutinya.

Keempat, setiap kelompok membuat perencanaan yang sistematik tentang proses pemecahan masalah pembelajaran. Melalui perencanaan tersebut, siswa dapat membagi tugas kepada masing-masing siswa untuk menyelesaikan setiap tahapan yang telah direncanakan. Anak-anak lebih suka merencanakan sebelum melakukan. Siswa akan saling berdebat untuk melakukan bagian yang mana terlebih dahulu dan kegiatan selanjtnya. Diskusi tersebut akan menentukan tahap kegiatan awal pembelajaran siswa. Dan kelima, guru berperan sebagai mediator dan sumber informasi bagi siswa yang mengalami kesulitan informasi untuk memecahkan masalah. Siswa taman kanak-kanak memiliki keterbatasan dalam mengolah infomasi di sekitar mereka sehingga peran guru menjadi sangat sentral dalam mengembangkan kemampuan berpikir siswa dalam mengolah informasi yang ada untuk memecahkan masalah pembelajaran.(Mundiri \& Zahra, 2017) 


\section{Kesimpulan}

Pembelajaran berbasis masalah merupakan strategi yang tepat untuk mengembangkan kemampuan siswa secara mandiri. Siswa taman kanak-kanak sangat tertarik terhadap berbagai masalah di sekitar mereka. Mereka melakukan percobaan-percobaan kecil untuk mengetahui tentang apa yang mereka dapat pelajari dari suatu masalah. Guru memiliki peran yang sangat penting dalam menyediakan kondisi pembelajaran yang kondusif bagai kegiatan pemecahan masalah yang dilakukan oleh siswa. siswa masih memerlukan banyak bimbingan dan arahan agar mereka mampu mempelajari berbagai cara dalam menyelesaikan berbagai permasalahan dalam pembelajaran.

\section{DAFTAR PUSTAKA}

Saleh, M. 2013. Strategi Pembelajaran Fiqh dengan Problem Based Learning, Jurnal Ilmiah DIDAKTIKA, 14(1): 191-120, (http://jurnal.arraniry.ac.id/index.php/didaktika/article /viewFile/497/415), diakses 11 Januari 2018.

Herman, T. 2007. Pembelajaran Berbasis Masalah untuk Meningkatkan Kemampuan Berpikir Matematis Tingkat Tinggi Siswa Sekolah Menengah Pertama. EDUCATIONIST, 1(1): 47-56, (http://file.upi.edu/Direktori/JURNAL/EDUCATIONIST/Vol._I_N o._1-Januari_2007/6._Tatang_Herman.pdf), diakses 11 Januari 2018.

Utomo, T., Wahyuni, D., dan Hariyadi, S. 2014. Pengaruh Model Pembelajaran Berbasis Masalah (Problem Based Learning) Terhadap Pemahaman 
Konsep dan Kemampuan Berpikir Kreatif Siswa (Siswa Kelas VIII Semester Gasal SMPN 1 Sumbermalang Kabupaten Situbondo Tahun Ajaran 2012/2013). Jurnal Edukasi Unej, 1(1): 5-9, (https://jurnal.unej.ac.id/index.php/JEUJ/article/download/1025/82 2/), diakses 11 Januari 2018.

Sunaryo, Y. 2014. Model Pembelajaran Berbasis Masalah Untuk Meningkatkan Kemampuan Berpikir Kritis Dan Kreatif Matematik Siswa SMA Di Kota Tasikmalaya. Jurnal Pendidikan dan Keguruan, 1(2): 42-51, (https://media.neliti.com/media/publications /209679-modelpembelajaran-berbasis-masalah-untu.pdf), diakses 11 Januari 2018.

K. Oktaviarini, A. 2015. Penerapan Model Pembelajaran Berbasis Masalah untuk Meningkatkan Kemampuan Komunikasi Matematis, Seminar Nasional Matematika dan Pendidikan Matematika, Halaman 77-82, (http://seminar.uny.ac.id/semnasmatematika/sites/ seminar.uny.ac.id.semnasmatematika/files/banner/PM-12.pdf), diakses 11 Januari 2018.

Baharun, H., \& Mundiri, A. (2011). Metodologi Studi Islam: Percikan Pemikiran Tokoh Dalam Membumikan Agama. Ar-Ruzz Media (1st ed.). Yogyakarta: Ar-Ruzz Media.

Mundiri, A. (2017). Organizational Culture Base On Total Quality Management In Islamic Educational Institution. ADRI International Journal Of Islamic Studies and Social Sciences, 1(1), 1-11.

Mundiri, A., \& Zahra, I. (2017). CORAK REPRESENTASI IDENTITAS USTADZ DALAM PROSES TRANSMISI PENDIDIKAN KARAKTER DI 
PESANTREN. Jurnal Pendidikan Islam, Vol. 2, No, 21-35. 